\title{
On the time-varying nature of the debt-growth nexus: Evidence from the euro area
}

\author{
Marta Gómez-Puig ${ }^{\mathrm{a}}$, Simón Sosvilla-Rivero ${ }^{\mathrm{b} *}$ \\ ${ }^{a}$ Department of Economic Theory, Universitat de Barcelona. 08034 Barcelona, Spain \\ ${ }^{\mathrm{b}}$ Complutense Institute for International Studies, Universidad Complutense de Madrid. \\ 28223 Madrid, Spain
}

July 2017

\begin{abstract}
This paper uses the DCC-GARCH model to investigate the existence of time-varying correlations between public debt and economic growth. To that end, we use annual data from both central and peripheral countries of the euro area for the period 1961-2015. The results suggest that the relationships between these variables are time-varying and that on some countries and for some periods, there is a positive association between them.
\end{abstract}

Keywords: Public debt, economic growth, time-varying approach, DCC, euro area.

JEL Classification Codes: C22, F33, H63, O40, O52

\footnotetext{
* Corresponding author. Tel.: +34 913942342; fax: +34 913942591

E-mail addresses: marta.gomezpuig@ub.edu (M. Gómez-Puig), sosvilla@ccee.ucm.es (S. Sosvilla-Rivero)
} 


\section{Introduction}

Over the last two decades, considerable attention has been devoted to role of public debt in economic growth and, although there is a large body of theoretical and empirical literature devoted to this issue, the results are far from conclusive [see Panizza and Presbitero (2013) for a survey].

The empirical studies have concentrated predominantly on the effect of the level of public debt on economic growth and largely ignored the possible relationship in the volatility of these variables ${ }^{1}$. Economic agents react negatively on the uncertainties about future taxes and the future behaviour of fiscal parameters implied by higher public debt. As Pindyck (1988) suggested predictable policies and clear rules of the game are important for private investors ${ }^{2}$. More recently, Fatás and Mihov (2013) show that the volatility of fiscal policy has a first-order effect on long-term economic performance.

In this paper we use the Dynamic Conditional Correlation (DCC) model developed by Engle (2002) to estimate and examine the time-varying nature of the debt-growth relationship between public debt and economic growth. The paper is organized as follow. Section 2 outlines econometric strategy. Section 3 presents the data and the empirical results. Section 5 provides some concluding remarks.

\section{Econometric strategy}

We use Engle's (2002) DCC model. This model is able to capture the volatility correlation between two series, either directly through its conditional variance or indirectly through its conditional covariances. The model is also able to examine the volatility spillover from one series to another, providing insight on both series' synchronization. The DCC has two stages. In the first step, the generalized autoregressive conditional heteroskedasticity $(\mathrm{GARCH})$ parameters are estimated. In the second step, the conditional correlations are estimated using the DCC method as follows:

$$
H_{t}=D_{t} R_{t} D_{t}
$$

\footnotetext{
${ }^{1}$ Cecchetti et al. (2011) report negative correlations of per capita GDP volatility with Government debt.

${ }^{2}$ The role of policy volatility can also be detected in Barro (1990).
} 
where $H_{t}$ is a $k x k$ conditional covariance matrix, $R_{t}$ is the conditional correlation matrix, and $D_{t}$ is diagonal matrix of time-varying standard deviations.

The likelihood of the DCC estimator is:

$$
L=-0.5 \sum_{t=1}^{T}\left(k \log (2 \pi)+2 \log \left(\left|D_{t}\right|\right)+\log \left(\left|R_{t}\right|\right)+\varepsilon_{t}^{\prime} R_{t}^{-1} \varepsilon_{t}\right) .
$$

The volatility $\left(D_{t}\right)$ and the correlation $\left(R_{t}\right)$ components may vary, thus the estimation process is achieved in two steps.

Firstly the volatility $\left(L_{v}\right)$ is maximized:

$$
L_{v}=-0.5 \sum_{t=1}^{T}\left(k \log (2 \pi)+\log \left(\left|D_{t}\right|^{2}\right)+r_{t}^{\prime} D_{t}^{-2} r_{t}\right)
$$

then the correlation $\left(L_{c}\right)$ is maximized:

$$
L_{c}=-0.5 \sum_{t=1}^{T}\left(\log \left(\left|R_{t}\right|\right)+\varepsilon_{t}^{\prime} R_{t}^{-1} \varepsilon_{t}-\varepsilon_{t}^{\prime} \varepsilon_{t}\right)
$$

Engle (2002) proposed a two-step estimation. The DCC model is estimated by a twostep procedure: a) in the first step univariate GARCH models are fitted for each the logdifference of each series and estimates of their variances are thus obtained; b) the logdifferences are filtered out of the GARCH effect by dividing by their estimated standard deviations and then are used to estimate the dynamics of correlation, $\varepsilon_{i t}=r_{i t} / \sqrt{h_{i t}}$. In the second step, the standardized residuals are used to estimate the time-varying correlation matrix.

The model developed by Engle (2002) has the following non-linear GARCH specification for the conditional correlation:

$$
Q_{t}=(1-a-b) \bar{Q}+a \varepsilon_{t-1} \varepsilon_{t-1}^{\prime}+b Q_{t-1}
$$

where $Q_{t}=\left(q_{i j, t}\right)$ is a $n x n$ symmetric positive definite matrix, $a$ and $b$ are nonnegative scalars such as $a+b<1$, a is the news coefficient and $b$ is the decay coefficient. $\bar{Q}=E\left(\varepsilon_{t} \varepsilon_{t}^{\prime}\right)$ is the unconditional variance matrix of the standardized residuals (the unconditional correlation). The conditional correlations $q_{i j, t}$ are time-varying and follow a structure similar to a $\operatorname{GARCH}(1,1)$ model. 
For ensuring a conditional correlation between -1 and +1 , by normalization the

correlation can be expressed $\rho_{i j, t}=q_{i j, t} / \sqrt{q_{i i . t} q_{j j . t}}$. The correlations are obtained by transforming this to:

$$
R_{t}=\left(\operatorname { d i a g } ( Q _ { t } ) ^ { - 0 . 5 } Q _ { t } \left(\operatorname{diag}\left(Q_{t}\right)^{-0.5}\right.\right.
$$

where $\left(\operatorname{diag}\left(Q_{t}\right)^{0.5}\right.$ is a diagonal matrix of the square root of the diagonal elements of $Q_{t}$.

\section{Data and empirical results}

We use annual data for eleven euro area countries, both central (Austria, Belgium, Finland, France, Germany and the Netherlands) and peripheral countries (Greece, Ireland, Italy, Portugal and Spain), covering the period 1961-2015. The ratio of public debt to Gross Domestic Product (GDP) comes from European Commission's AMECO database, and the growth rate of real per capita GDP comes from the World Bank. Figure 1 shows the evolution of sovereign debt-to-GDP and real GDP per capita growth in the 11 countries of our sample.

\section{[Insert Figure 1 here]}

Figure 2 reports the estimated dynamic conditional correlations ${ }^{3}$. As can be seen, the time-varying conditional correlation is negative throughout all the period in Austria, Germany and Italy and through all the period but very few exceptions in Finland (1.82\%). However, it moves from positive to negative values in France, Greece, Ireland, the Netherlands, Portugal and Spain. Especially striking is the behavior of the dynamic conditional correlation between debt and growth in the Netherlands and Spain, where it presents positive values in $41.82 \%$ and $38.18 \%$ of sample period, respectively. As for the temporal distribution of positive DCC, $27.17 \%$ are detected in the 1980 s, $25 \%$ in the $1990 \mathrm{~s}, 19.57 \%$ in the $1970 \mathrm{~s}$ and $17.39 \%$ in the 2000s. Interestingly, a comparison of Figures 1 and 2 suggest that most of the estimated positive values coincide with significant reductions in debt-to-GDP ratios associated with serious fiscal adjustment processes. This finding is in line with the experience of middle-income developing countries in the late 1980s (Chari and Henry, 2014), providing further support to the possibility of reducing the debt burden as important part of a pragmatic growth strategy

\footnotetext{
${ }^{3}$ To save space, the estimation results for the DCC-GARCH models are not shown here, but available from the authors upon requests.
} 
when it is implemented in concert with reforms that raise productivity and provide a business environment in which firms have an incentive to generate output, invest in capital, and employment.

[Insert Figure 2 here]

\section{Concluding remarks}

This article can be thought of as a reexamination of the standard paradigm relating public debt to economic growth, by using the DCC-GARCH model to investigate the existence of time-varying correlations between those variables.

If correct, the results of our empirical analyses have strong policy implications, since countries are often advised to make strong and rapid fiscal adjustments during recessions. We find that, on some countries and for some periods, there is a positive association between public debt and economic growth coinciding with significant consolidation efforts. This result seems to provide some support the popular policy recipe, prominently advocated by Alesina and Perotti $(1995,1997)$ and Giavazzi and Pagano (1990), that large spending-based fiscal consolidations are likely to have expansionary effects on the economy. Nevertheless, the speed of progress toward a specified fiscal target is an open question, since gradualism can be a powerful tool in helping achieve the objectives of a broader growth strategy (Dewatripont and Roland, 1995).

A natural extension to the analysis presented in this paper would be to explore the main determinants of the detected differences in the relationships between public debt and economic growth across countries, with special emphasis in the institutional factors as suggested by Hall and Jones (1999), Acemoglu (2009) and Acemoglu and Robinson (2012), as well as their economic structure, the nature of the shocks they face, and the government's policy regime. This is an item in our future research agenda. 


\section{Acknowledgements:}

Simón Sosvilla-Rivero thanks the Department of Economics for their hospitality during a research visit at the University of Bath.

\section{Funding:}

This work was supported by the Instituto de Estudios Fiscales [grant IEF 015/2017], the Banco de España [grant PR71/15-20229]; the Spanish Ministry of Education, Culture and Sport [grant PRX16/00261]; and the Spanish Ministry of Economy and Competitiveness [grant ECO2016-76203-C2-2-P].

\section{References}

Acemoglu, D., 2009. Introduction to Modern Economic Growth. Princeton University Press, Princeton.

Acemoglu, D., Robinson, J., 2012. Why Nations Fail. Crown Publishing Group, New York.

Alesina, A., Perotti, R., 1995. Fiscal expansions and adjustments in OECD economies. Economic Policy 21, 207-247.

Alesina, A., Perotti, R., 1997. Fiscal adjustments in OECD countries: Composition and macroeconomic effects. International Monetary Fund Staff Papers 44, 210-248.

Barro, R., 1990. Government spending in a simple model of endogenous growth. Journal of Political Economy 98, 103-125.

Chari, A., Henry, P. B. (2014): Learning from the doers: Developing country lessons for advanced economy growth. American Economic Review 104, 260-265

Cecchetti, S., Mohanty, M., Zampolli, F., 2011. Achieving growth amid fiscal imbalances: The real effects of debt, in: Economic Symposium Conference Proceedings. Federal Reserve Bank of Kansas City, Kansas City, pp. 145-196.

Dewatripont, M.,, Roland, G (1995). The design of reform packages under uncertainty. American Economic Review 85, 1207-1223. 
Engle, R.F., 2002. Dynamic conditional correlation: A simple class of multivariate generalized autoregressive conditional heteroskedasticity models. Journal of Business and Economic Statistics 20, 339-350.

Fatás, A., Mihov, I., 2013. Policy volatility, institutions, and economic growth. Review of Economics and Statistics 95, 362-376.

Giavazzi, F., Pagano, M., 1990. Can severe fiscal contractions be expansionary? Tales of two small European countries. NBER Macroeconomics Annual 5, 75-122.

Hall, R. E., Jones, C. I., 1999. Why do some countries produce so much more output per worker than others? Quarterly Journal of Economics 114, 83-116.

Panizza, H., Presbitero, A. F., 2013. Public debt and economic growth in advanced economies: A survey. Swiss Journal of Economics and Statistics 149, 175-204.

Pindyck, R. S., 1988. Irreversible investment, capacity, choice, and the value of the firm. American Economic Review 78, 969-985, 
Figure 1. Sovereign Debt-to-GDP and GDP per capita growth evolution in EMU countries: 1960-2015

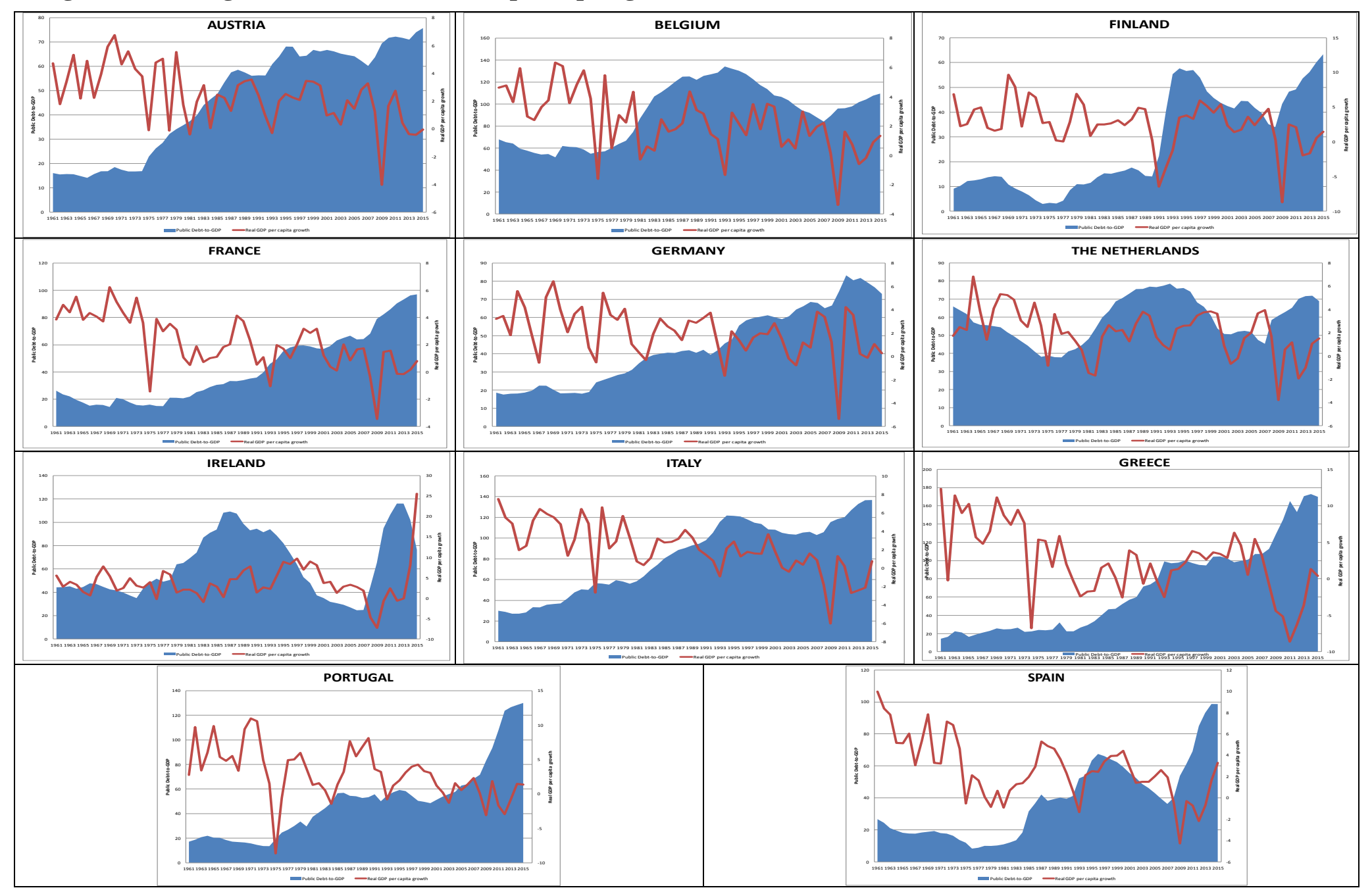

Note. Source: Note: Source AMECO and WDI 
Figure 2. Dynamic Conditional Correlation between sovereign debt-to-GDP and GDP per capita growth in EMU countries: 1960-2015

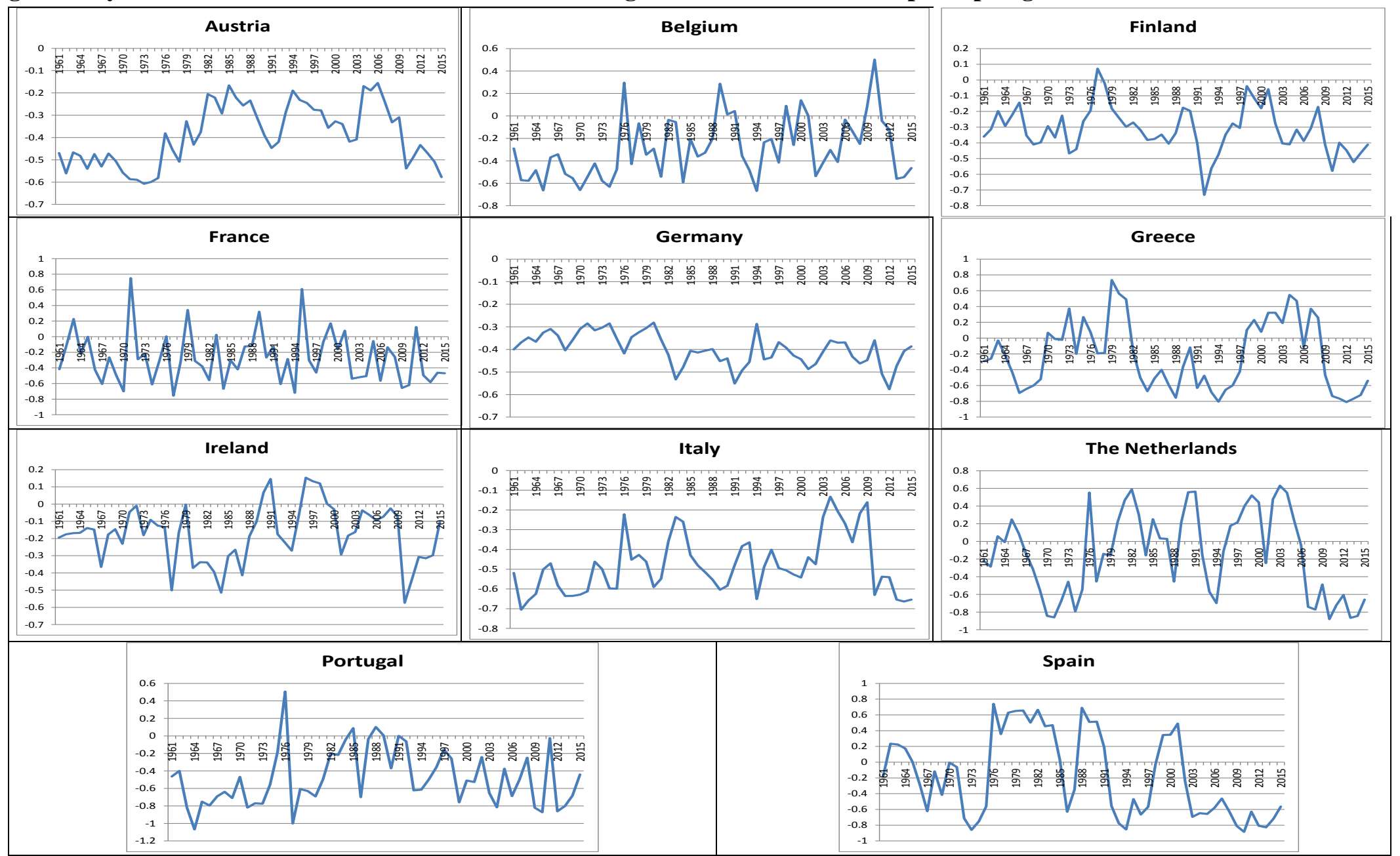

Note. Source: AMECO, WDI and own estimates 